Water and Ritual 
The Linda Schele Series in Maya and Pre-Columbian Studies

This series was made possible through the generosity of William C. Nowlin, Jr., and Bettye H. Nowlin, the National Endowment for the Humanities, and various individual donors. 


\section{Water and Ritual}

\section{The Rise and Fall of Classic Maya Rulers}

LISA J. LUCERO

University of Texas Press 
Copyright $(C 2006$ by the University of Texas Press

All rights reserved

Printed in the United States of America

First edition, 2006

Requests for permission to reproduce material from this work should be sent to:

Permissions

University of Texas Press

P.O. Box 7819

Austin, TX 78713-7819

www.utexas.edu/utpress/about/bpermission.html

(0) The paper used in this book meets the minimum requirements of ANSI/NISO Z39.48-I992 (RI997) (Permanence of Paper).

\section{Library of Congress Cataloging-in-Publication Data}

Lucero, Lisa Joyce.

Water and ritual : the rise and fall of classic Maya rulers / Lisa J. Lucero.- Ist ed.

p. $\quad$ cm. - (The Linda Schele series in Maya and pre-Columbian studies)

Includes bibliographical references and index.

ISBN 0-292-70999-4 (cloth : alk. paper)

I. Mayas-Politics and government. 2. Mayas-Kings and rulers. 3. Mayas-

Rites and ceremonies. 4. Water rights-Central America. 5. Water rights-

Mexico. 6. Water-Religious aspects. 7. Central America-Economic conditions.

8. Mexico-Economic conditions. I. Title. II. Series.

FI435.3.P7L83 2006

$305.897^{\prime} 42-\mathrm{dc} 22$ 
For my parents, Jim and Ida Lucero 
THIS PAGE INTENTIONALLY LEFT BLANK 